\title{
AN EMPIRICAL EXAMINATION OF THE RELATIONSHIP BETWEEN CEOS AND DIRECTORS
}

\author{
Catherine M. Daily \\ The Ohio State University \\ Columbus, $\mathrm{OH}$
}

\begin{abstract}
This study examines the relationship between CEO characteristics and board composition, as well as the relationship between board composition and board roles. Canonical correlation analysis demonstrates strong support for the relationship between CEO characteristics and board composition. No support was found, however, for the relationship between board composition and board roles. While CEOs are associated with the composition of the board, this relationship does not appear to be associated with the board's ability to discharge their service, resource, and control roles.
\end{abstract}

\section{Introduction}

The past several years have witnessed a renewed interest in firms' strategic leaders (Hambrick 1989). Sutton and Callahan, for example, have noted that "images of organizations and their leaders are intertwined" (1987, p. 405). Both CEOs and members of corporate boards are recognized as influential organizational leaders (e.g., Boeker 1992; Hambrick 1981; Pettigrew 1992). Given their importance in influencing firm processes and outcomes, the nature of the relationship between CEOs and directors continues to be of interest.

One of the critical issues in strategic leadership research is the extent to which CEOs influence the directors to whom they report (e.g., Mace 1971; Vancil 1987; see also Pettigrew 1992). For example, CEOs are widely regarded as influencing the director nomination process by selecting directors with whom they would be most comfortable working (e.g., Fredrickson, Hambrick and Baumrin 1988). One of the chief criteria employed by CEOs during the director nomination process is that the director nominee be "compatible" with the CEO (Wheelen and Hunger 1990). In turn, directors appointed by CEOs often accommodate them by rubber-stamping executive decisions (e.g, Patton and Baker 1987).

The process described enables CEOs to influence the composition of the board. CEOs desiring strong control positions, for example, may elect to invite a preponderance of inside (management) directors to serve on the board. Even outside directors who feel no particular obligation to the CEO may be limited in their capacity to challenge CEO actions, as they are largely dependent upon the CEO for firm specific information (Aram and Cowan 1983; Zald 1969). While the proportion of outside to total directors has been the most extensively re- 
searched board composition measure (e.g., Zahra and Pearce 1989), the total numbers of directors, as well as minority and women director representation, have been found to be important components of the composition of the board of directors (e.g., Chaganti, Mahajan and Sharma 1985; Kesner 1988; Patton and Baker 1987; Pearce and Zahra 1991).

The director nomination process, and its potential implications for board composition, is just one example of the importance of the relationship between CEOs and directors (e.g., Pfeffer and Salancik 1978). These relationships may be particularly salient for those CEOs who achieved their positions at relatively early ages. CEOs of major corporations typically do not ascend to their positions until sometime in their early to mid-50s (Vancil 1987). Moreover, this ascent typically follows many years of working through the ranks of the firm (Vancil 1987). Consequently, those CEOs who are appointed at a relatively young age may have very different experiences and face different challenges than their older counterparts, especially in their relationships with the board of directors. To date, however, no one has addressed the associations between young CEOs and the boards of directors of the firms they serve.

The purpose of this research is to enhance our understanding of the relationship between firms' CEOs and boards of directors. Specifically, we examine the extent to which enduring CEO traits are associated with the composition of the board and, consequently, with the board's ability to fulfill its service, resource, and control roles. The model depicted in Figure 1 will be developed and tested, focusing on the association between CEO characteristics and board composition and the association between board composition and board roles.

We rely on a specialized sample of young, successful CEOs. We are aware of no research that addresses the relationship between CEOs and board composition and roles for young executives. We also focus on modestly sized firms. While examples of young, powerful CEOs are found among the largest of U.S. firms (e.g., Business Week 1991), they are more typically found in modestly sized firms and those that are privately held (e.g., Eisenhardt and Schoonhoven 1988; Whisler 1988). It has been suggested that perhaps the most logical place to find CEO effects is in the smaller firm where the CEO is less constrained and monitored (e.g., Dalton and Kesner 1983; Norburn and Birley 1988). In the modestly sized firm, where it may be easier to advance to the position of CEO at an early age, leadership is generally concentrated and decision making is typically centralized around the CEO (Begley and Boyd 1986; Whisler 1988). Should CEO/board effects be found, then, they are likely to emerge in smaller firms where the CEO may have a more "hands on" relationship with the board (e.g., Daily and Dalton 1993). 


\section{Figure 1 \\ The Relationship Between CEO Characteristics and Board Composition and Roles}

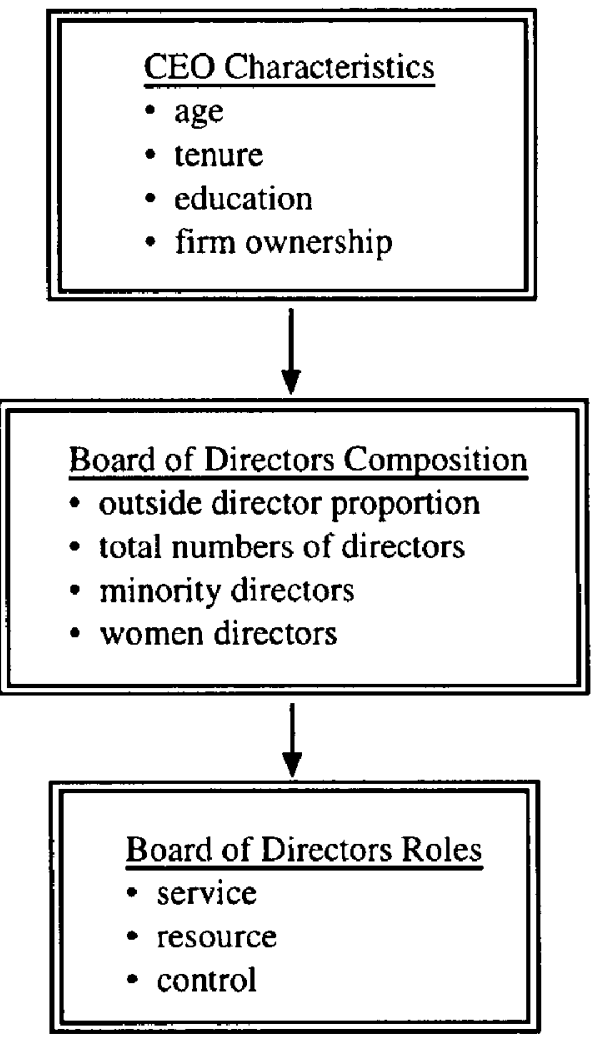

\section{CEOs and Board Composition}

\section{CEO Characteristics}

Despite a considerable amount of attention to board composition, scant attention has been paid to the relationship between CEOs and alternative board configurations. One means for addressing this relationship is the consideration of demographic variables in examinations of strategic leaders (Finkelstein and Hambrick 1990; Hambrick and Mason 1984; Michel and Hambrick 1992; Wiersema 1992). Reliance upon demographic measures provide several advantages in organizational research, including "objectivity, parsimony, and possible replication" (Michel and Hambrick 1992, p. 16). In addition, researchers are increasingly finding support for the importance of executive traits in organizational research (e.g., Wiersema and Bantel 1992). Inclusion of demographic variables may be particularly important in strategic leadership research because investigations of executives' background, experiences and values inform the choices they make (Finkelstein and Hambrick 1990), including elected governance structures. 


\section{Board Composition}

As previously mentioned, CEOs may play a significant role in determining the composition of the board, in part, to assemble a board that is unlikely to challenge their power and authority (Rosenstein 1987). When the board is comprised predominately of outsiders, for example, CEOs may have to work harder to convince directors to adopt their point of view. Alternatively, a board composed of insiders may be more easily controlled by the CEO (Brady and Helmich 1984). Should the CEO be more interested in strengthening his or her power base than in constructing a representative board, he or she might elect to have a small board with low proportions of outside directors and little minority or female representation.

By considering CEOs' age, tenure, educational level, and level of firm ownership we can begin to assess the relationship between executive characteristics and the composition of the board of directors. Executive characteristics may be especially important in examinations of young CEOs. For example, there may be degrees of "youth" that can be captured by examining the extent to which age, within a constrained sample, is related to board composition. Also, factors such as tenure as CEO, educational level, and equity stake in the firm may prove equally as important.

\section{CEO Age}

An executives' age has long been found to affect organizational decision processes and outcomes (e.g., Finkelstein and Hambrick 1990). Younger executives, for example, have consistently been found to be associated with innovativeness and risk (Carlsson and Karlsson 1970). Older executives tend to be more conservative and less likely to initiate strategic change (Stevens, Beyer and Trice 1978; Wiersema and Bantel 1992). Associations between executive youth and company growth have been posited, as well (Child 1974; Hambrick and Mason 1984).

If youth is positively associated with executives' propensity to initiate change and foster firm growth, we might expect younger CEOs to invite greater numbers of outside directors for board service to enhance the number of alternative perspectives available. We might also anticipate the total size of the board, as well as representation from external stakeholder groups represented by minority and women directors, to increase. Their older, more conservative, colleagues might elect opposite strategies as a less risky approach.

$\mathrm{H}_{1}$ : $\mathrm{CEO}$ age will be negatively associated with outside director proportion and total numbers of directors, as well as representation of women and minorities on the board.

\section{CEO Tenure}

Long tenure may be an indication of CEO's entrenchment (Fredrickson et al. 1988; Mallette and Fowler 1992). As the CEO's tenure is extended, the board's allegiance and values will more closely approximate those of the CEO 
(Fredrickson et al. 1988). As tenure within the organization increases, one's knowledge base may become increasingly limited (Cyert and March 1963) so insiders may be more reluctant to take on strategies involving new terrain (Hambrick and Mason 1984). Additionally, over time firms' executives become embedded in organizational inertia, making it difficult for them to carry out major changes in organizational direction (Wiersema 1992). Finkelstein and Hambrick (1990), for example, found that longer tenured executive teams followed more persistent strategies that conformed to industry standards.

Here, too, we might expect that CEOs with shorter tenures would be more likely to invite outside directors, who could presumably offer alternative perspectives and perhaps help initiate change, and increase the total resource base with greater numbers of directors and women and minority director representation. CEOs who have been with the organization for longer periods of time, however, may be more reticent to change and see this form of board as a threat to the status quo.

$\mathrm{H}_{2}$ : CEO tenure will be negatively associated with outside director proportion and total numbers of directors, as well as representation of women and minorities on the board.

\section{CEO Education}

Executives' education level, too, may be an important factor, as it serves as an indicator of a person's knowledge and skill base (Hambrick and Mason 1984). Associations between educational level and openness to changes have also been found. Kimberly and Evanisko (1981), for example, demonstrated that more highly educated executives are more receptive to new ideas. In addition, linkages between educational level and firms' strategic posture have been shown. Thomas, Litschert, and Ramaswamy (1991), for example, found that executives in prospector firms were younger, had shorter tenures, and had more education than executives in defender firms.

These studies indicate that more highly educated executives may be more willing to pursue more innovative strategies. The inclusion of outside directors, greater overall board size, and the inclusion of minority and women directors on the board would serve as one mechanism for garnering the external support and expertise necessary to initiate and implement these strategies.

$\mathrm{H}_{3}$ : CEO educational level will be positively associated with outside director proportion and total numbers of directors, as well as representation of women and minorities on the board.

\section{CEO Firm Ownership}

CEOs' financial stake in the firm may also impact board composition. Firm ownership furthers a CEO's ability to influence the selection of directors (Fredrickson et al. 1988). Allen (1981) and Allen and Panian (1982) have found that significant levels of firm ownership serve as a measure of CEO power. Some discussion of the level of firm ownership needed to exercise control has been 
advanced. Jensen and Warner (1988), however, have found that executives with as little as five percent ownership stake have considerable organizational power.

If control is the preeminent concern of CEOs, it would be unlikely that they would invite directors who are apt to challenge or constrain their actions. Consequently, outside directors and minority and women directors who may bring alternative perspectives and agendas may be excluded from board service. Additionally, smaller boards which are more manageable are likely to be associated with greater levels of CEO firm ownership.

$\mathrm{H}_{4}$ : CEO equity ownership will be negatively associated with outside director proportion and total numbers of directors, as well as representation by women and minorities on the board.

\section{Board Composition and Roles}

Much of the discussion regarding directors' roles focuses on the composition of the board, particularly the proportion of outside directors. Board composition is believed to be an important factor with regard to the service, resource, and control roles of the board (Pearce and Zahra 1992). The following sections outline the importance of these roles, as well as the relationship between board composition and board roles. These relationships are important because the ability of directors to perform their roles may be largely dependent on the composition of the board (Pearce and Zahra 1992).

\section{Service Role}

Directors fulfill the service role primarily through the quality of counsel and advice provided to CEOs. Outside directors, by virtue of their independence from the management of the firm, are believed to best fill this role. The importance of the service role was demonstrated by Chitayat (1984), who found that board chairpersons believed consulting with and coaching the CEO were the most critical aspects of their jobs. Additionally, Stewart (1991) has found that CEOs appreciate a board chairperson on whom they can rely for advice and counsel.

The service role may be particularly valuable for the young CEO who, while arguably a powerful organizational force, may not possess the level of industry experience needed to make optimal choices for the firm. Additionally, the external perception that a young CEO lacks the necessary experience and credentials to effectively run the organization may negatively impact the firm. A notable example of this occurred when Bill Gates, CEO of MicroSoft, began interacting with external firm constituents (Wallace and Erickson 1992). Here, carefully selected outside directors may help the firm overcome this perception by enhancing the firm's general reputation and credibility.

\section{Resource Role}

The second role provided by boards of directors is resource acquisition. This role is related to the service role and advocates appointing representatives 
of significant external constituencies as outside board members (e.g., Pfeffer and Salancik 1978; Selznik 1949). Such appointments can be viewed as a strategy for managing organizations' environmental relationships. In this role, directors serve as boundary spanning agents who coopt critical external constituencies with which they are interdependent (Pfeffer and Salancik 1978).

Cooptation of these individuals represents a means of effectively managing organizational dependence (e.g., Mintzberg 1983; Zald 1969). Outside directors provide access to valued resources and information, facilitate interfirm commitments, and aid in establishing legitimacy (e.g., Bazerman and Schoorman 1983; Pfeffer and Salancik 1978; Provan 1980). Also, outside directors may be better able to protect the organization from environmental adversity (Pearce and Zahra 1992). This role may also be especially critical for the firm with a relatively young CEO. With less exposure to the external community than a more senior CEO, the firm may significantly benefit from the access to external resources that outside directors can provide.

\section{Control Role}

The final role involves the board's monitoring function (Anderson and Anthony 1986; Mintzberg 1983; Vance 1983; Waldo 1985). This may be the most critical of the board functions, as it is this role that has received the most attention from board reform critics. Outside directors are believed to be most effective in discharging this role. Inside directors, due to their subordinate position in the organization, are unlikely to aggressively monitor and evaluate CEO actions (Dalton and Rechner 1989; Fleischer, Hazzard and Klipper 1988; Harrison, Torres and Kukalis 1988; Patton and Baker 1987; Rosenstein 1987). The issue is the extent to which inside directors can avoid conflicts likely to arise in attempting to maintain loyalty to the CEO while evaluating his or her actions (e.g., Baysinger and Hoskisson 1990; Kesner and Dalton 1986; Lorsch and MacIver 1989; Geneen 1984).

These concerns are particularly valid for inside directors reporting to an influential CEO. Beyond the influence typical of a CEO in a modest sized firm, CEOs who have ascended to their positions at relatively young ages may possess substantially more organizational influence. Bill Gates and Steve Jobs provide two notable examples of young, influential CEOs (Wallace and Erikson 1992). The probability of active oversight on the part of inside directors, then, is significantly lessened.

Based on the preceding arguments, it may be that outsiders are more able to responsibly fulfill their directoral roles. The inclusion of minority and women directors may also be consistent with the resource acquisition role (see e.g., Kesner 1988; Pearce and Zahra 1991). These individuals may have linkages to the external environment that provide the firm with a competitive advantage. Kesner (1988), for example, found that women directors were typically outside directors, suggesting that perhaps they represented significant external constituencies. The overall size of the board may also be positively related to fulfilling the three board 
roles. It is sensible that greater numbers of directors increase the available expertise and resource pool.

$\mathrm{H}_{5}$ : Greater board representation by outside, minority, and women directors, as well as total numbers of directors, will be associated with greater board involvement in the service, resource acquisition, and control roles of the board.

\section{Method}

\section{Sample}

The participation of a mid-western chapter of the Young Presidents Organization (YPO) was solicited for this study. This group was primarily chosen due to the accessibility of the CEO. In addition, these CEOs are typically young, successful CEOs with operating responsibility for relatively modestly sized firms. The YPO is comprised of individuals who achieved the title of President/CEO prior to their 40th birthdays. Members may join at anytime prior to their 40th birthday, however. Additionally, members' firms must maintain gross annual revenues of at least four million dollars and employ at least 50 people. Financial corporations must retain an average of 80 million dollars in assets. YPO members must retire from the organization the year following their 50th birthday. These members, therefore, are young, high profile, influential executives.

The survey instrument was sent to the total membership of the YPO chapter $(n=82)$ via the chapter President. The mailing was coordinated through the chapter President due to members' concerns about confidentiality. The care in protecting the identities of respondents provides some confidence that the CEOs were candid in their responses to survey items. Forty usable surveys were returned, for a response rate of 48.78 percent. This response rate is well within the acceptable range for this type of research (Alpar and Spitzer 1989).

\section{Variables}

CEO characteristics: Respondents identified their age, tenure in the position of CEO, education level (secondary, undergraduate, or graduate degree), and percentage of firm ownership.

Board composition is operationalized in four ways. The first is simply the proportion of outside directors. The definition of outside directors as it appeared on the survey instrument was adapted from Pearce and Zahra (1991) and read as follows: "Outside directors have been defined as directors who are not members of the top management team, their associates, or families; are not employees of the firm or its subsidiaries; and are not members of the immediate past top management group." Total numbers of directors, total number of minority directors, and total number of women directors were also included.

Board roles were assessed with a nine item, seven-point Likert scale. These items were developed based on previous research (e,g., Ford 1988). Factor analysis (see Tables $1 \mathrm{a}$ and $1 \mathrm{~b}$ ) revealed three factors meeting the service, 
resource and control roles. Due to the low sample size we also conducted a confirmatory factor analysis. These results supported the three distinct factors, with factor loadings similar to those reported in Table 1a. Factor reliabilities are provided in Table $1 c$.

Table 1a

Factor Analysis of Board Activities

\begin{tabular}{|l|c|c|c|}
\hline Item & $\mathbf{1}$ & $\mathbf{2}$ & $\mathbf{3}$ \\
\hline Active in strategic planning & .78 & & \\
\hline Provides financial expertise & .73 & & \\
\hline Provides CEO advice and counsel & .71 & & \\
\hline Contacts to external community & & .80 & \\
\hline Enhance firm reputation and credibility & & .80 & \\
\hline Provides technological expertise & & .78 & \\
\hline Top management succession plans & & & .77 \\
\hline Monitors CEO performance & & & .61 \\
\hline Reviews management proposals & & & .54 \\
\hline
\end{tabular}

Table 1b

Factor Eigenvalues and Names

\begin{tabular}{|c|c|c|c|}
\hline & Factor Name & Eigenvalue & $\begin{array}{c}\text { Explained } \\
\text { Variance }\end{array}$ \\
\hline Factor 1 & Service & 3.53 & 39.3 \\
\hline Factor 2 & Resource & 1.44 & 16.0 \\
\hline Factor 3 & Control & 1.14 & 12.6 \\
\hline & & $\begin{array}{c}\text { Total } \\
\text { Explained } \\
\text { Variance }\end{array}$ & $67.9 \%$ \\
\hline
\end{tabular}

Table 1c

Scale Reliabilities

\begin{tabular}{|l|c|c|c|c|}
\hline $\begin{array}{l}\text { Scale } \\
\text { Name }\end{array}$ & $\begin{array}{c}\text { No. of } \\
\text { Items }\end{array}$ & $\begin{array}{c}\text { Mean } \\
\text { Value }\end{array}$ & $\begin{array}{c}\text { Std. } \\
\text { Dev. }\end{array}$ & $\begin{array}{c}\text { Alpha } \\
\text { Coeff. }\end{array}$ \\
\hline Service & 3 & 14.76 & 4.18 & .75 \\
\hline Resource & 3 & 12.00 & 5.05 & .76 \\
\hline Control & 3 & 12.18 & 4.22 & .64 \\
\hline
\end{tabular}


Two control variables were included in the analyses: firm size and firm age. These variables have been found to be important in strategic leadership research (e.g., Fredrickson et al. 1988; Michel and Hambrick 1992; Wiersema and Bantel 1992). The inclusion of these variables is based on the work of Freeman, Carroll, and Hannan (1983) who found that organizations typically suffer from two major liabilities: newness and smallness. Numerous studies, for example, have shown that an organization's age affects organizational processes (e.g., Boeker 1989; Eisenhardt 1988; Tolbert and Zucker 1983).

Firm size is operationalized as the number of full-time employees. Past research has found that sales, assets, and number of employees are equally appropriate indicators of a firm's size (e.g., Harrison et al. 1988). Firm age was calculated based on the year the firm was founded.

\section{Analysis}

We rely on canonical correlation analysis for hypothesis testing. These hypotheses are characterized by interrelated, interval level dependent variables. Also, the independent variables are interval level. Accordingly, the relationship between the independent variables and the dependent variables must be simultaneously assessed. Therefore, canonical correlation is the appropriate analytical technique. In order to clarify interpretation of these results, we report both simultaneous and separate analyses for the dependent variables.

\section{Results}

Table 2 presents the means, standard deviations, and inter-item correlations for all variables included in the study. Respondents' average age was 44.75 years and they had been in their current positions as CEO/President for an average of 8.83 years. Consistent with the membership criteria for YPO, these individuals were just under 36 years old when they assumed their roles as CEO/President. CEOs' age and tenure for this sample can be compared to what might be expected for CEOs of large firms. The average age of CEOs in the largest U.S. firms is in the mid 50s; these CEOs have served in their current positions for approximately 14 years (Business Week 1991; Vancil 1987).

Seven and one-half percent of the respondents had obtained high school degrees, 47.5 percent of respondents held undergraduate degrees, and 45 percent held graduate degrees as their highest level of educational achievement. These findings are quite similar to that of large firm CEOs, 47 percent of whom hold graduate degrees (Business Week 1991). The level of firm ownership ranges from zero to 100 percent, with an average of 34.8 percent. This level of ownership is substantially more than might be found among large firm CEOs (Business Week 1990).

The first four research questions address the relationship between CEO characteristics and board composition. Given the interval level nature of both the independent and dependent variables, and the interrelationships between the dependent variables, these hypotheses can be assessed simultaneously with canoni- 
Table 2 Means, Standard Deviations, and Inter-item Correlations"

\begin{tabular}{|c|c|c|c|c|c|c|c|c|c|c|c|c|c|c|}
\hline Variable & Mean & sd & 1 & 2 & 3 & 4 & 5 & 6 & 7 & 8 & 9 & 10 & 11 & 12 \\
\hline 1. CEO age & 44.75 & 6.43 & & & & & & & & & & & & \\
\hline 2. CEO tenure & 8.83 & 5.92 & 27 & & & & & & & & & & & \\
\hline $\begin{array}{l}\text { 3. CEO } \\
\text { educational } \\
\text { level }\end{array}$ & 2.38 & .63 & 34 & -22 & & & & & & & & & & \\
\hline $\begin{array}{l}\text { 4. CEO firm } \\
\text { ownership }\end{array}$ & 34.80 & 35.97 & 00 & $45^{* *}$ & 01 & & & & & & & & & \\
\hline $\begin{array}{l}\text { 5. Outside } \\
\text { director } \\
\text { proportion }\end{array}$ & .41 & .30 & 33 & -07 & 13 & 06 & & & & & & & & \\
\hline $\begin{array}{l}\text { 6. Total number } \\
\text { of directors }\end{array}$ & 6.80 & 4.83 & 32 & -06 & $41^{*}$ & $-45^{* *}$ & 00 & & & & & & & \\
\hline $\begin{array}{l}\text { 7. Minority } \\
\text { directors }\end{array}$ & .08 & .27 & $44^{*}$ & 14 & 01 & -26 & -22 & $41 * *$ & & & & & & \\
\hline $\begin{array}{l}\text { 8. Women } \\
\text { directors }\end{array}$ & .50 & .88 & .02 & 10 & 07 & -31 & -17 & $56 * * *$ & 27 & & & & & \\
\hline 9. Services & 14.76 & 4.18 & 03 & $44^{*}$ & -24 & 28 & 09 & -04 & 08 & 17 & & & & \\
\hline 10. Resources & 12.00 & 5.05 & 18 & 17 & 13 & -10 & 04 & 30 & 07 & 06 & $47 * *$ & & & \\
\hline 11. Control & 12.18 & 4.22 & $49 * *$ & 19 & 08 & 14 & 19 & 16 & 26 & 04 & $49^{* *}$ & 25 & & \\
\hline 12. Firm size & 694.48 & 1441,00 & $51 * *$ & -13 & 31 & $-35^{*}$ & -21 & $64 * * *$ & $67^{* * *}$ & 24 & -06 & 10 & 24 & \\
\hline 13. Firm age & 47.75 & 28.45 & $-39^{*}$ & 02 & -16 & 15 & -28 & $-56 * * *$ & .16 & -25 & 05 & -14 & -14 & $-40^{*}$ \\
\hline
\end{tabular}


cal correlation analysis. The results indicate a significant multivariate test of significance (see Table 3), indicating that CEO characteristics are important indicators of the composition of the board of directors.

Canonical correlation analysis was also used to assess the relationship between board composition and board roles. These results did not support the existence of a relationship since neither the multivariate test nor the univariate tests were significant (see Table 4).

Table 3

Canonical Correlation Analysis CEO Characteristics and Board Composition

\begin{tabular}{|c|c|c|c|c|c|}
\hline \multicolumn{6}{|c|}{ Multivariate Test of Significance } \\
\hline $\begin{array}{l}\text { Dependent } \\
\text { Variable }\end{array}$ & Test & $\mathbf{F}$ & $\mathrm{df}$ & $\begin{array}{l}\text { error } \\
\text { df }\end{array}$ & sig. \\
\hline Multivariate & Wilks & 2.5111 & 24 & 128 & .001 \\
\hline \multicolumn{6}{|c|}{ Univariate Tests of Significance } \\
\hline Dependent Variable & Test & F & $\mathrm{df}$ & $\begin{array}{l}\text { error } \\
\text { df }\end{array}$ & sig. \\
\hline $\begin{array}{l}\text { Outside director } \\
\text { proportion }\end{array}$ & Reg. & 2.4692 & 6 & 32 & .045 \\
\hline $\begin{array}{l}\text { Total number } \\
\text { of outside directors }\end{array}$ & Reg. & 5.5029 & 6 & 32 & .001 \\
\hline Minority directors & Reg. & 2.5543 & 6 & 32 & .039 \\
\hline Women directors & Reg. & 1.0440 & 6 & 32 & .416 \\
\hline
\end{tabular}

Table 4

Canonical Correlation Analysis Board Composition and Board Roles

\begin{tabular}{|l|c|c|c|c|c|}
\hline $\begin{array}{l}\text { Multivariate Test of Significance } \\
\text { Variable }\end{array}$ & Test & F & df & $\begin{array}{c}\text { error } \\
\text { df }\end{array}$ & sig. \\
\hline Multivariate & Wilks & .6629 & 18 & 90.0 & .837 \\
\hline \multicolumn{7}{|l|}{ Univariate Tests of Significance } \\
\hline $\begin{array}{l}\text { Dependent } \\
\text { Variable }\end{array}$ & Test & F & df & $\begin{array}{c}\text { error } \\
\text { df }\end{array}$ & sig. \\
\hline Service & Reg. & .3635 & 6 & 30 & .896 \\
\hline Resource & Reg. & .5734 & 6 & 30 & .748 \\
\hline Control & Reg. & .4545 & 6 & 30 & .836 \\
\hline
\end{tabular}




\section{Discussion}

These results highlight the continuing importance of demographic traits in strategic management research (e.g., Michel and Hambrick 1992; Wiersema and Bantel 1992). CEO characteristics were found to impact three aspects of board composition. Univariate tests indicated effects for the proportion of outside directors, total number of outside directors and the presence of minority directors on the board. These effects were not significant for female directors.

It is instructive to examine the univariate tests to ascertain which demographic variables contribute most to the multivariate function. The demographic variables that were significantly associated with outside director proportion included CEO age $(t=2.57, p<.05)$, firm ownership $(t=2.32, p<.05)$, and firm size $(t=-2.58, p<.05)$. Presence of minority directors is most affected by the size of the firm $(t=2.43, p<.05)$. The overall size of the board is associated with CEOs' educational level $(t=2.13, p<.05)$, firm size $(t=2.48, p<.05)$, and firm age $(t=-3.10$, $\mathrm{p}<.01)$.

Based on large firm research, we know that the ability to influence the director nomination process increases as CEOs extend their years of service with their organizations (e.g., Pfeffer and Salancik 1978). This study suggests that associations between CEOs and directors may not be markedly different for young CEOs. This, coupled with a smaller sized firm, may enable the CEO to impact important organizational processes such as the selection of directors. Contrary to critics who suggest CEOs' first concern is further entrenching their positions in their firms, these results suggest that as CEOs aged the potential benefits to including outside and minority directors became more apparent. The mature CEO may be less likely to feel threatened by the inclusion of "outside" directors and may, therefore, be more likely to include these individuals on the board as conditions warrant. A similar rationale might hold for CEOs' ownership levels. A CEO with significant ownership in the firm (an average of over 34 percent for this sample) may be unlikely to feel threatened by directors of any particular character or persuasion.

A related finding is that of the positive relationship found between a CEO's educational level and overall board size. The enhanced confidence with which more highly educated CEOs approach their business environment may enable them to invite greater numbers of directors to assist in the strategic positioning of the firm. These results also suggest the importance of including firm size and firm age as control variables in strategic leadership research.

These results provide preliminary evidence that young CEOs do carefully select directors for board service. Compatibility seems to be only one criteria for such selection, however (Wheelen and Hunger 1990). These findings may also suggest that building a board most capable of providing external resources (i.e., expertise and external firm contacts) is more important to CEOs than entrenching themselves in the organizations they lead. Perhaps achieving success at a relatively young age increases the confidence of CEOs. With this enhanced confi- 
dence, they may feel free to invite the diversity of opinion which is likely to accompany greater proportions of outside directors, larger boards, and board representation from historically under-represented groups.

Board composition was not found to be related to the board's ability to fulfill the service, resource, and control functions. Despite consistent admonitions from board reform critics (e.g., Dayton 1984; Geneen 1984) to increase the proportion of outside, minority, and women directors, no support was found for this position when relying on board roles as outcome variables. There was no systematic relationship between the four measures of board composition and the level of activity for board roles.

\section{Limitations}

The results of this study should be interpreted cautiously. Several limitations affect these findings. The lack of significance when considering the relationship between board composition and roles is likely influenced by (1) the preliminary nature of this examination and (2) the reliance upon only the CEO's perceptions of board roles. While the board role factors of service, resource acquisition, and control achieved acceptable reliability coefficients (alpha $=.75, .76$, .64 respectively), it is necessary to further investigate the strength and applicability of these scales. Additionally, replications of this study are needed due to the limited sample size.

This study focused exclusively on the CEO; however, assessing directors' perceptions of their involvement in service, resource, and control activities is necessary, as well. Ford (1988), for example, in a survey of directors of the Inc. 500 found that outside directors were less influential than their insider counterparts in traditional areas of the board's domain.

An additional limitation is that these analyses do not include comparisons of CEO and board characteristics with firm performance. Consistent with past survey research, respondents were reluctant to provide financial data. This reluctance was complicated by the high rate of private firm ownership ( 72.5 percent) as compared to publicly-held corporations ( 27.5 percent). Of the forty surveys returned, as few as 21 ( 47.5 percent) contained the requested financial information. Comparison tests were performed on all variables included in this study, however, and no significant differences were found between those respondents providing financial data and those who did not.

Lastly, reliance on only young CEOs limits generalizability. Future research would be well directed at further examining the potential uniqueness of CEOs who attain their positions early in life. Direct comparisons between young CEOs and those who are older also carry much potential.

\section{Conclusion}

Critics often charge that CEOs exert far too strong an influence on firm processes and outcomes. While CEOs who are relatively young and operating in 
modestly sized firms are strongly associated with the composition of the board, the resultant board make up does not appear to be related to the ability of directors to perform their service, resource acquisition, and control roles. The findings reported here suggest that further attention to the CEO characteristics and the extent to which these characteristics are associated with firm processes and outcomes is warranted. The results of this study lead us to conclude that organizational observers still have much to learn about the interactions between boards of directors and the CEOs who serve them.

\section{References}

Allen, M. P. "Managerial Power and Tenure in the Large Corporation." Social Forces 60 (1981): 484-494.

Allen, M. P., and S. K. Panian. "Power, Performance, and Succession in the Large Corporation." Administrative Science Quarterly 27 (1982): 538-547.

Alpar, P., and D. Spitzer. "Response Behavior of Entrepreneurs in a Mail Survey." Entrepreneurship: Theory and Practice 14, No. 20 (1989):31-44.

Anderson, C. A., and R. N. Anthony. The New Corporate Directors. New York: John Wiley, 1986.

Aram, J. D. and, S. A. Cowan. Information for Corporate Directors; The Role of the Board in the Management Process. New York: N. A. A. Press, 1983.

Baysinger, B. D., and R. E. Hoskisson. "The Composition of Boards of Directors and Strategic Control." Academy of Management Review 15 (1990): 72-87.

Bazerman, M. H., and F. D. Schoorman. "A Limited Rationality Model of Interlocking Directorates." Academy of Management Review 8 (1983): 206-217.

Begley, T. M., and D. P. Boyd. "Executive and Corporate Correlates of Financial Performance in Smaller Firms." Journal of Small Business Management 24, No. 2 (1986): 815.

Boeker, W. "Strategic Change: The Effects of Founding and History." Academy of Management Journal 32 (1989): 489-515.

Boeker, W. "Power and Managerial Dismissal: Scapegoating at the Top." Administrative Science Ouarterly 37 (1992): 400-421.

Brady, G. F., and D. L. Helmich. Executive Succession: Toward Excellence in Corporate Leadership. Englewood Cliffs, NJ: Prentice-Hall, 1984.

Business Week. "The Corporate Elite." (October 19, 1990): 8-14. 
Business Week. "The Corporate Elite." (November 25, 1991): 180-184.

Carlsson, G., and K. Karlsson. "Succession and Performance Among School Super intendents." American Sociological Review 35 (1970): 267-304.

Chaganti, R., V. Mahajan, and S. Sharma. "Corporate Board Size, Composition and Corporate Failures in Retailing Industry." Journal of Management Studies 22 (1985): 400416.

Child, J. "Managerial and Organizational Factors Associated with Company Performance." Journal of Management Studies 11 (1974): 13-27.

Chitayat, G. 1984. "Working Relationships Between the Chairman of the Board of Directors and the CEO." Management International Review 24, No. 1 (1984): 65-70.

Cyert, R., and J. March.. A Behavioral Theory of the Firm. New Jersey: Prentice-Hall, 1963.

Daily, C. M., and D. R. Dalton. "Board of Directors Leadership and Structure: Control and Performance Implications." Entrepreneurship: Theory and Practice 17 (1993): 65-81.

Dalton, D. R., and I. F. Kesner. "Inside/outside Succession and Organizational Size: The Pragmatics of Executive Replacement." Academy of Management Journal 26 (1983): 736742.

Dalton, D. R., and P. L. Rechner. 1989. "On the Antecedents of Corporate Severance Agreements: An Empirical Assessment." Journal of Business Ethics 8 (1989): 455-462.

Dayton, K. N. "Corporate Governance: The Other Side of the Coin." Harvard Business Review 62 (184): 34-37.

Eisenhardt, K. M. "Agency- and Institutional-theory Explanations: The Case of Retail Sales Compensation." Academy of Management Journal 31 (1988): 488-511.

Eisenhardt, K. M., and C. B. Schoonhoven. "Organizational Growth: Linking Founding Team, Strategy, Environment, and Growth Among U.S. Semiconductor Ventures, 19781988." Administrative Science Quarterly 35 (1988): 504-529.

Finkelstein, S., and D. C. Hambrick. "Top-Management-Team Tenure and Organizational Outcomes: The Moderating Role of Managerial Discretion." Administrative Science Quarterly 35 (1990): 484-503.

Fleischer, A., G. C. Hazzard, and M. Z. Klipper. Board Games: The Changing Shape of Corporate Power. Boston, MA: Little, Brown, 1988.

Ford, R. H. "Outside Directors and the Privately-owned Firm: Are They Necessary?" Entrepreneurship Theory and Practice 13 (1988): 49-57. 
Fredrickson, J. W., D. C. Hambrick, and S. Baumrin. "A Model of CEO Dismissal." Academy of Management Review 13 (1988): 255-270.

Freeman, J., G. Carroll, and M. Hannan. "The Liability of Newness and Age Dependence in Organizational Death Rates. American Sociological Review 48 (1983): 692-710.

Geneen, H. "Why Directors Can't Protect Shareholders." Fortune (September 17, 1984): 28-32.

Hambrick, D. C. "Strategic Awareness Within Top Management Team." Strategic Management Journal 2 (1981): 263-279.

Hambrick, D. C. "Putting Top Managers Back in the Strategy Picture." Strategic Management Journal 10 (1989): 5-15.

Hambrick, D. C., and P. A. Mason. "Upper Echelons: The Organization as a Reflection of its Top Managers." Academy of Management Review 9 (1984): 193-206.

Harrison, J. R., D. L. Torres, and S. Kukalis. "The Changing of the Guard: Turnover and Structural Change in the Top-Management Positions." Administrative Science Quarterly 33 (1988): 211-232.

Jensen, M. C., and J. B. Warner. "The Distribution of Power Among Corporate Managers, Shareholders, and Directors." Journal of Financial Economics 20 (1988): 3-24.

Kesner, I. F. "Directors' Characteristics and Committee Membership: An Investigation of Type, Occupation, Tenure, and Gender." Academy of Management Journal 31 (1988): 6684.

Kesner, I. F., and D. R. Dalton. "Boards of Directors and the Checks and (Im)balances of Corporate Governance." Business Horizons 29 (1986): 17-23.

Kimberly, J. R., and M. J. Evanisko. "Organizational Innovation: The Influence of Individual, Organizational and Contextual Factors on Hospital Adoption of Technological and Administrative Innovations." Academy of Management Journal 24 (1981): 689-713

Lorsch, J. W., and E. MacIver. Pawns or Potentates: The Reality of America's Corporate Boards. Boston, MA: Harvard Business School Press, 1989.

Mace, M. L. Directors: Myth and Reality. Boston, MA: Harvard University, 1971.

Mallette, P., and K. L. Fowler. "Effects of Board Composition and Stock Ownership on the Adoption of 'Poison Pills'." Academy of Management Journal 35 (1992): 10101035.

Michel, J. G., and D. C. Hambrick. "Diversification Posture and Top Management TeamCharacteristics." Academy of Management Journal 35 (1992): 9-37. 
Mintzberg, H. Power In and Around Organizations. Englewood Cliffs, NJ: Prentice Hall, 1983.

Norburn, D., and S. Birley. "The Top Management Team and Corporate Performance." Strategic Management Journal 9 (1988): 225-238.

Patton, A., and J. C. Baker. "Why Do Directors Not Rock the Boat?" Harvard Business Review 65 (1987): 10-18.

Pearce, J. A., and S. A. Zahra. "The Relative Power of CEOs and Boards of Directtors: Associations with Corporate Performance." Strategic Management Journal 12 (1991): 135153.

Pearce, J. A., and S. A. Zahra. "Board Composition from a Strategic Contingency Perspective." Journal of Management Studies 29 (1992): 411-438.

Pettigrew, A. M. "On Studying Managerial Elites." Strategic Management Journal 13 (1992): 163-182.

Pfeffer, J., and G. R. Salancik. The External Control of Organizations: A Resource Dependence Perspective. New York: Harper \& Row, 1978.

Provan, K. G. "Board Power and Organizational Effectiveness Among Human Service Agencies." Academy of Management Journal 23 (1980): 221-236.

Rosenstein, J. "Why Don't U.S. Boards Get More Involved in Strategy?" Long Range Planning 20 (1987): 20-34.

Selznik, P. TVA and the Grass Roots: A Study in the Sociology of Formal $Q r$ ganization. New York: Harper \& Row, 1949.

Stevens, J. M., J. M. Beyer, and H. M. Trice. "Assessing Personal Role, and Organizational Predictors of Managerial Commitment." Academy of Management Journal 18 (1978): 74-81.

Stewart, R. "Chairmen and Chief Executives: An Exploration of their Relationship." Journal of Management Studies 28 (1991): 511-527.

Sutton, R. I., and A. L. Callahan. "The Stigma of Bankruptcy: Spoiled Organizational Image and its Management." Academy of Management Journal 30 (1987): 405-436.

Thomas, A. S., R. J. Litschert, and K. Ramaswamy. "The Performance Impact of Strategy-Manager Coalignment: An Empirical Examination." Strategic Management Journal 12 (1991): 509-522.

Tolbert, P. S., and L. G. Zucker. "Institutional Sources of Change in the Formal Structure of Organizations: The Diffusion of Civil Service Reforms, 1880-1935." Administrative Science Quarterly 23 (1983): 22-39. 
Vance, S. C. Corporate Leadership: Boards, Directors, Strategy. New York: McGraw Hill, 1983.

Vancil, R. Passing the Baton: Managing the Process of CEO Succession. Boston, MA: Harvard Business School Press, 1987.

Waldo, C. N. Boards of Directors: Their Changing Roles, Structure, and Information Needs. Westport, CT: Quorum Books, 1985.

Wallace, J., and J. Erickson. Hard Drive. New York: HarperBusiness, 1992.

Wheelen, T. L., and J. D. Hunger. Strategic Management. Reading, MA: Addison-Wesley Publishing Company, 1990.

Whisler, T. L. "The Role of the Board in the Threshold Firm." Family Business Review 1 (1988): 309-321.

Wiersema, M. F. "Strategic Consequences of Executive Succession within Diversified Firms." Journal of Management Studies 29 (1992): 73-94.

Wiersema, M. F., and K. A. Bantel. "Top Management Team Demography and Corporate Strategic Change." Academy of Management Journal 35 (1992): 91-121.

Zahra, S. A., and J. A. Pearce. "Boards of Directors and Corporate Financial Performance: A Review and Integrative Model." Journal of Management 15 (1989): 291-334.

Zald, M. "The Power and Functions of Boards of Directors: A Theoretical Synthesis." American Journal of Sociology 75 (1969): 97-111. 